\title{
3Д-3 \\ ИНВЕРСИОННАЯ ВОЛЬТАМПЕРОМЕТРИЯ НА ТВЕРДОМ ИНДИКАТОРНОМ ЭЛЕКТРОДЕ ДЛЯ КОНТРОЛЯ ВАЛЕНТНЫХ ФОРМ ТОКСИКАНТОВ
}

\author{
Алексеева Н.А., Ануфриева О.Ю. \\ ООО «Аналитические исследовательские приборы», Санкт-Петербург, Россия \\ analyt@list.ru
}

DOI: 10.26902/ASFE-11_141

Химические элементы в окружающей среде и в живых организмах находятся в определенных формах, характеризуемых степенью окисления, структурой молекулы или комплекса и другими факторами. В зависимости от форм, в которых существуют элементы в объектах, их соединения обладают различными токсичными свойствами. Поэтому определение общего (валового) содержания элементов бывает малоинформативным при оценке их канцерогенного воздействия на живые организмы. Наибольшее внимание исследователей привлекает определением валентных форм $\mathrm{Se}, \mathrm{As}, \mathrm{Hg}, \mathrm{Cr}$ [1]. Известно, что $\mathrm{As}^{3+}$ более токсичен, растворим и подвижен, чем $\mathrm{As}^{5+}$, поэтому изучение процессов, влияющих на восстановление $\mathrm{As}^{5+}$ до $\mathrm{As}^{3+}$ в объектах, является необходимым в задачах оценки их токсичности, и связано с необходимостью определения валентных форм As [2]. Окислительные свойства $\mathrm{Cr}^{6+}$ обуславливают его гетерогенные и канцерогенные свойства в то время, как $\mathrm{Cr}^{3+}$ не проявляет выраженных токсичных свойств из-за невозможности проникновения через клеточные мембраны живых организмов [1]. При контроле состояния экологических объектов практически во всех странах, включая Россию, нормируется как валовое содержание, так и подвижные валентные формы $\mathrm{Cr}^{6+}$ [3]. Представленные примеры свидетельствуют о важности задач надежного определения валентных форм токсичных элементов.

В лабораториях, оборудованных спектральными анализаторами и хроматографами, могут быть использованы аналитические методы в комбинации, например, жидкостная хроматография и ИСП-МС. Так же одним из эффективных методов для решения подобных задач, является инверсионная вольтамперометрия (далее - ИВ) на твердом индикаторном электроде. Метод ИВ позволяет с высокой точностью определять микроконцентрации электрохимически активных валентных форм токсичных элементов, представляющих наибольший интерес для изучения. Так, электрохимически активной валентной формой мышьяка в ИВ является $\mathrm{As}^{3+}$, а в анализируемых растворах методом ИВ определяется токсичные валентные формы $\mathrm{Cr}^{6+}$ и $\mathrm{Se}^{4+}$.

На рынке отечественного приборостроения существует ряд приборов, реализующих метод инверсионной вольтамперометрии на твердом индикаторном электроде и позволяющих с высокой надежностью определять микроконцентрации токсичных валентных форм химических элементов. Программные и методические разработки позволяют обеспечить следующую чувствительность при анализе методом ИВ: $\mathrm{As}^{3+}-0,2 \mathrm{ppb} ; \mathrm{Cr}^{6+}-5,0 \mathrm{ppb} ; \mathrm{Se}^{4+}$ $0,02 \mathrm{ppb}$.

\section{Список литературь}

1. Иваненко Н.Б., Соловьев Н.Д., Иваненко А.А., Москвин Л.Н. Определение химических форм микроэлементов в биологических объектах// Аналитика и контроль. 2012.Т 16. №2. с.108-133.

2. П у т и л и н а В. С., Галицкая И.В., Юганова Т.И. Поведение мышьяка в почвах, горных породах и подземных водах. Трансформация, адсорбция / десорбция, миграция. Аналит. обзор. Новосибирск: ГПНТБ СО PAH, 2011. - $249 \mathrm{c}$.

3. Семенкова И.Н., Королева Т.В. Международные системы нормирования содержания химических элементов в почвах: принципы и методы (обзор)//Почвоведение. 2019. №10. с.1-10. 